\title{
Gautier d'Arras, Éracle
}

\section{G. Matteo Roccati}

\section{(2) OpenEdition}

\section{Journals}

\section{Édition électronique}

URL : https://journals.openedition.org/studifrancesi/38898

DOI : 10.4000/studifrancesi.38898

ISSN : 2427-5856

\section{Éditeur}

Rosenberg \& Sellier

\section{Édition imprimée}

Date de publication : 1 décembre 2004

Pagination : 331

ISSN : 0039-2944

\section{Référence électronique}

G. Matteo Roccati, «Gautier d'Arras, Éracle », Studi Francesi [En ligne], 143 (XLVIII | II) | 2004, mis en ligne le 30 novembre 2015, consulté le 19 mai 2021. URL : http://journals.openedition.org/ studifrancesi/38898; DOI : https://doi.org/10.4000/studifrancesi.38898

\section{Ce document a été généré automatiquement le 19 mai 2021}

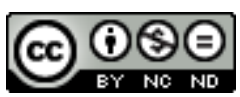

Studi Francesi è distribuita con Licenza Creative Commons Attribuzione - Non commerciale - Non opere derivate 4.0 Internazionale. 


\title{
Gautier d'Arras, Éracle
}

\author{
G. Matteo Roccati
}

\section{RÉFÉRENCE}

GAUTIER D'ARRAS, Éracle, Traduit en français moderne d'après l'édition de G. Raynaud de Lage par André ESKÉNAZI, Introduction et dossier par Corinne PIERREVILLE, Paris, Honoré Champion Éditeur («Traductions des Classiques du Moyen Age», 54), 2002, pp. 248.

1 L'introduction (pp. 7-38) présente l'auteur et l'oeuvre. Sont soulignés en particulier La diversité de l'inspiration dans les différentes parties du roman et Le souci de la réalité qui y apparait et qui ouvre la voie au roman «réaliste» du siècle suivant; sont également traitées les parentés d'Eracle avec Erec et Cligès de Chrétien ainsi que la possible influence du roman sur ce dernier dans le Conte du Graal, dont la composition est postérieure. Des Notes sur la traduction (passages amendés, difficultés dans le texte, principes suivis; pp. 39-65) précèdent la traduction, suivie d'une série d'annexes (pp. 215-233) où sont reproduits des extraits de différentes oeuvres dont on trouve l'écho à l'intérieur d'Eracle (textes religieux, Cligès, littérature épique, Légende dorée). La bibliographie et l'index des noms propres (avec renvois à l'édition Raynaud de Lage, 1976) terminent le volume. 